\title{
NEW VIEWS ON THE HYPOGEUM AND TARXIEN
}

\section{Ian F.G. Ferguson}

One of the tasks set us by archaeologists and scientists is to conceptualise spans of time ever increasing with the refinements of science, such as radiocarbon dating and its calibration. Our current task in this field is to conceptualise the millennia back to $10,000 \mathrm{~B} . \mathrm{C}$., the end of the last Ice Age, and beyond. The calibrated radiocarbon dates, as established by Professor Renfrew and others, place the first wave of immigrants to Malta around 5000 B.C., and the second wave around 4000 .

With such immense periods, the dangers of unconscious anachronisms are considerable. These dangers include treating such concepts as "goddesses and gods" as being personified and named deities, the concept of "worship" in relation to cult activities, and the idea of human conception, that is, of the male role as well as of the selfevident birth-giving act of the female. Major problems also exist in interpreting cultic, religious and philosophical ideas from material remains. "The beliefs of past societies are an integral aspect which the archaeologist cannot afford to ingore, however difficult their reconstruction may seem." (Champion et al. 1984: 142). Different types of material remains are discovered; a quern has an easily recognisable function, but an icon does not. The correct technique must be the detailed examination of the object per se, comparison with similar objects, and then reference back to its archaeological context.

\section{"THE FAT LADY"}

The Tarxien temples form the largest temple complex in Malta, and this figure, the so-called "Fat Lady" (Pl. 19) is found inside the Western Temple, one of the last of the Maltese temples, dated to around 3000 B.C. This figure, which must originally have been over 2 metres high, is perhaps the earliest piece of monumental sculpture in the world's history. Sadly she has been quarried away till only her impressive lower parts remain. Professor Evans comments, "The figure was undoubtedly portrayed as seated. Some of the statuettes at Tarxien give a good idea of what she must have looked like when complete. The base of the statue is set into the slab, which is cut out to receive it (Pl. 24). This slab is $1.30 \mathrm{~m}$ long and $16.5 \mathrm{cms}$ high and the front of it is sculptured with a kind of primitive egg and dart motif." 
(Evans 1971: 129). A related view is given by Mr Ridley: "The motif carved on the panel is both unique and interesting. It consists of a row of horizontal ovoids with pointed ends, 'eggs', separated by 'double axes' or concave and convex lines" (Ridley 1976: 78). At this conference we have already heard Mr. Cutajar's interesting interpretation that they represent bobbins and loom-weights, an idea I do not wish to discount as the art here, in its religious context, is clearly symbolic and symbols are normally polyvalent. However Mr Cutajar himself admits that the perforation of the bobbins is missing.

It is easy to think of eggs here, but unfortunately the domestic fowl is an anachronism, as it was not introduced into Europe from India until the first millennium. And how about the other elements, the 'darts' or 'double axes"? There is no evidence that the neolithic Maltese had either, and in fact there is a good alternative explanation. In the Museum at Tarxien are three upright querns about two feet high, two of which have just this outline (Pl. 23); another is in the National Museum in Valletta. The typology of the Maltese neolithic querns has not received enough attention: many types exist, including the long low quern of coralline limestone built into the temple at Kordin and having seven compartments, various simple querns, some of lava from Sicily, suitable for individual households, and these raised querns which appear suitable for ritual use while standing in front of a cult figure. So, the motif now appears, not as 'eggs and axes', but as exactly seven ritual querns which separate six enlarged representations of wheat or barley grains. This interpretation is completely compatible with the neolithic Maltese farming community.

If correct, this helps dramatically in identifying the "Fat Lady". By Roman times the slab was buried under over a metre of silt, but any Roman looking at the motif and the cult figure would have thought of her as Ceres, while the Greeks would have related her to DemeterDemeter was actually a pre-Greek goddess only tardily accepted into the Greek Olympus, and she was especially characterised as the goddess of corn responsible for the fertility of the tilled soil. I am not claiming that the "Fat Lady" was called by some such name as Ceres or Demeter: this would be an anachronism, as the personifying anthropomorphisms of the deities in this area was a feature of the late second and the first millennia. Now the older and more correct title of Athene was "potni' Athenai", using the genitive, "Our Lady of Athens." This corresponds to the earlier Cretan goddess whose style, according to our translation of the Linear B tablets was "Our Lady of the Labyrinth." So our neolithic Maltese, whatever their language, probably referred to their local form of the Goddess by a title equivalent to "Our Lady of Tarxien." 


\section{THE HYPOGEUM: BURIALS}

The Hypogeum at Hal Saflieni is unique, though there may well be others awaiting future archaeologists in the Maltese limestone. It was discovered in 1902, but since its systematic excavation from 1904 -11 by the father of the Maltese archaeology, Sir Temi Zammit, little further progress has been made, apart from the Survey in 1953 by Professor Evans and Mr Wright. I quote now from Dr Trump: "This must be the most remarkable monument in the Mediterranean, in Europe, perhaps in the world, but we are almost totally ignorant of what went on in it, or the other temples" (Trump 1980, 143). This is a challenge I wish to take up.

The Hypogeum is comparable to a mediaeval cathedral in that it was a sacred place gradually developed and extended over the course of many centuries (probably more than a millennium), coming to contain a variety of uses in its three levels. Its use ended with the abandonment of the temples and the end of the neolithic Maltese civilisation around $2500 \mathrm{~B}$.C. and extends back from this point in time to the early part of the fourth millennium. We have evidence of various activities being performed there, of which the most evident is that of burial. When Dr Zammit excavated the Hypogeum, he estimated the large number of human bones as belonging to around 7000 individuals. These came from the upper and middle levels and were generally covered with earth. He also discovered an intact crouched human skeleton which probably represents the last individual to be buried there. So we are probably justified in distinguishing between an initial primary burial following the individual's death, followed at a discrete interval by dispersal or secondary burial, still within the Hypogeum. This interval quite likely corresponds to the period of mourning which would have followed the funeral rites and lasted until the secondary burial when the spirits of the departed "joined those of the ancestors." A smaller chamber or cave, when full, would have been cleared of its bones and soil to make way for new occupants, the earlier burials being disposed of collectively in a larger ossuary area.

Professor Renfrew has estimated the Neolithic population of Malta as approximately 11,000 , averaging about 2000 for each of the six major centres. The figure could perhaps be around 2500 here, as Tarxien boasted the largest temple complex, and the Hypogeum could have been used by the inhabitants of Kordin as well. Now the average lifespan in contemporary Neolithic Orkney was around 20 years, and if the average lifespan in Mediterranean Malta was as high as 30 years, even at a population of 2500 , the Hypogeum could have reached its 
total of 7000 in less than a century. However, in the absence of substantial radiocarbon readings, all the available evidence (pottery, etc) points to its use over many centuries. Hence, burial in the Hypogeum was probably strictly selective, possibly being inherited by certain families. Yet this was essentially collective burial without noticeable grave goods.

Linked with its primary function as a place of burial was presumably a cult of the dead ancestors, probably linked with animal sacrifice at the funeral itself. The Main Hall here is the most remarkable room left us by the ancient Maltese. Like the rest of the Hypogeum it has been carved out of the living globigerina limestone, yet unlike all the other rooms it does not have the feeling of a cave. This is because a concave temple facade of noble and harmonious proportions has been carved out of the rock, and this combines with three long lintels which introduce the features of a corbelled vault. This is architecture: the combination of an external temple facade with internal 'corbelling' is most admirable and ingenious, and with the high polish of the stone endows this 'chapel' with an air of great serenity and solemnity. However, the scale precludes congregational worship (itself an anachronistic Christian idea), so we have probably to envisage the funeral ceremonies being attended mainly by the members of the extended family group.

Evidence of cult usages elsewhere in the Hypogeum are the stone figurines of 'Our Lady', the painted designs in red ochre, and possibly the various entry trilithons which are also found in the temple entrances. Another indication of cult use, that of incubation, is provided by the famous terracotta Sleeping Lady and her companion piece which we will be considering shortly, associated with two cubicles opening into the Main Hall. There was possibly an oracular use too; this is more problematic and is linked to the so-called oracle-hole: this does indeed provide remarkable echoes, but echo does not constitute real proof of its use. The oracle-hole could equally well have been used to contain a stone icon; its interior is painted with three red discs which do seem to indicate some cultic function.

\section{THE SLEEPING LADY}

We now come to the famous Sleeping Lady of the Hypogeum, a terracotta figurine which is a small masterpiece of the craftman's art. The lady, whoever she is, dressed in a full-length skirt, ample-hipped and topless à la maltaise ancienne, is lying full length on a low couch or bed, head on a block in lieu of a pillow, clearly asleep, almost visibly 
dreaming. But who was she? What was she doing sleeping in this most spooky of all possible places, and why was the piece made? Was she indeed a priestess?

This fascinating piece is generally taken as representing the rite of incubation. In the classical world, which is almost all we have to go by, incubation was closely associated with cults of healing, and none of these was more famous than that of Asklepios at Epidauros. Medical treatment was beginning to gain some scientific status in the Greek world, but incorporated many weird and many superstitious elements. Sufferers from bodily and mental ailments were common then as now, treatment inevitably was often unsuccessful, and the centre at Epiduaros, with its temple to the divinised hero Asklepios, had gained a wide reputation for successful cures by the fifth century B.C.

The treatment at Epidauros consisted of an initial purification of the patient by washing and fasting, followed by a night spent in the temple of Asklepios. The next morning the patient's dreams were recounted to the attendant priest who used this information to develop a prescription which paid attention to general régime and diet. So this cult at Epidauros was a kind of medical divination using dreams. Votive offerings from cured and grateful patients were a common feature at the sites of healing cults in the ancient world. The offerings were typically terracotta models of the body or bodily parts cured legs, arms, breasts, even wombs. The Romans inherited such cults from the Etruscans, the Greeks from the Minoans who had such a cult centre at Petsofa. Even today many Mediterranean churches have chapels with similar votive offerings, often now in plastic. Lourdes itself is a sacred centre associated with a cult of healing. And the ancient Maltese apparently had such a centre of their own at the temple of Mnajdra, where the 'oracle' was associated with a cult of healing. Several terracotta models of diseased or deformed bodies have been found there, and among these Dr Zammit diagnosed one, a woman with an abnormally swollen abdomen, as suffering from an abdominal tumour. The Hypogeum has been linked with an oracle, and if so, the piece called the Sleeping Lady could be a votive offering from one who successfully passed through the rite of incubation in the Hypogeum. But if so, what was she suffering from? I shall attempt to answer this question shortly.

\section{THE HYPOGEUM: CONTEXT FOR INCUBATION}

We have already seen the link that existed in ancient times between incubation, oracles and cults of healing, but we have yet to 
consider one of the most important medical complaints. Perhaps the clay models of wombs are our clue, pointing to the problems of the women who were barren. Certainly to a neolithic community of farmers, a woman who was barren would seem like one accursed, one suffering from that curse they must have feared falling on their land, their animals and themselves. Even today, with all the benefits of modern science, hormonal treatment, artificial insemination, etc., there are plenty of women who experience great difficulty in becoming pregnant. The Old Testament bears witness to the plight of the barren wife in a patriarchal society.

Symbolically the Hypogeum at $\mathrm{Hal}$ Saflieni represents a labyrinthine womb, and it is most unlikely that the early Maltese were not conscious of this symbolism. Our Lady must have been their symbol of fertility and new life. Just as these early farming folk depended on the good earth producing rich, not meagre, harvests of cereals, pulses and other crops, so they depended on the reproductive fertility of their cows, sheep, goats and pigs and - equally important and fundamental - on their own fertility to maintain the numbers of the Maltese community. Here in Malta the temple-builders had established a successful relationship with the forces of nature that regulated their destiny. We cannot test their ideas about destiny, but it is likely that, like similar groups elsewhere, they held beliefs about the perpetuation and periodic renewal of the vital forces of life.

However, up to the present there has been a general but tacit assumption on the part of prehistorians and archaeologists that prehistoric communities normally shared the view of historic societies about the causal relationship between sex and reproduction. This well could be a serious anachronism, and it is not a view shared unreflectingly by all. Anthropologists, sociologists and cultural historians have recognised this problem. Sir James Frazer was one of these; in his Golden Bough (Part IV, Book I) he quotes specific cases of some two dozen twentieth century communities where there was common denial of any male role in reproduction. His examples assemble the Hurons, various European groups including Slavs, several African tribes, a Syrian community (this is an Islamic society!), various tribes across India, others in Australia.

A classic in anthropology is Bronislaw Malinowski's description of his field work during World War I among the Trobriand Islanders in the Pacific, who, he found, did not share our ideas; they viewed sexual intercourse as a natural event to be enjoyed from puberty onwards, but 
they had established no causal nexus between human sexual activity and pregnancy. On the contrary, they believed in a form of reincarnation in which spirit children who wished to be reborn would cross to the Trobriand Islands where they would choose their future mothers and enter their wombs. They rejected the usual view when it was explained to them, and it is both remarkable and significant that they ascribed no role to the male in the reproductive process. None of this, of course, amounts to proof for the neolithic Maltese, but the range of examples in time as well as in space undoubtedly establishes it as a serious possibility. Here I wish to quote Professor Gimbutas: "There is no evidence that in Neolithic times mankind understood biological conception" (Gimbutas 1983: 237). With her I submit that the onus of proof in this matter lies just as heavily on those who assume, without proof, that neolithical peoples shared our own ideas: I think this is a serious anachronism.

This problem of conceptualising the different roles of male and female in reproduction could well be the cause of another related contrast phenomenon, that between the matrilinear and the patrilinear way of tracing descent. In fact there is just a little evidence to hint that our ancient Maltese may, in the course of the millennia, have made the discovery of the male role for themselves. I refer to the erection of cylindrical phallic stones, baetyls or lingams (to use the Indian term) within or beside the temples. They are especially associated with Ggantija, Hagar Qim and Tarxien, and in the first two cases were deliberately associated with a downpointing triangular or 'female' stone. These baetyls are not integral parts of the temples, they were later additions. To this evidence we must add the late carving of bulls on the walls at Tarxien, and also the carved stone phalli from the same site; these must surely have had ritual use - one is actually double! Would it be surprising if these Maltese farmers, as their control and knowledge of stock-breeding increased, had made this discovery for themselves, and had developed new ritual, incorporating these symbolic stone structures in their temples?

\section{REINCARNATION}

I return now to the Sleeping Lady and the other sleeper, two terracotta figurines which are posing us some searching questions. Why should mature women from the neolithic farming community have visited the Hypogeum, their sacred burial ground, perhaps by night, for some kind of dream? The commonest explanation is that they went there to induce dreams, possibly prophetic or oracular 
dreams, which they could subsequently interpret with the aid of the priesthood. Though extrapolated back in time by two millennia, this is a possible explanation: we all know the tale of Joseph intrepreting Pharaoh's dream. Yet this practice was never common; even the Etruscans, those master-diviners of the ancient world, are not known to have practised divination by dream. Another point: unlike the goddess figurines, our neolithic Maltese sleepers are buxom, emphatically female; so there is another possibility to consider.

The fact is that, from the evidence, this was no general form of dreaming, but a specific act deliberately planned to take place inside the Hypogeum, so perhaps the Hypogeum, the context of the rite, itself contains the key to the riddle. We see that the walls and ceilings of two rooms carry paintings which depict meandering vines bearing round, disc-like fruit which could easily be pomegranates. Clearly the paintings are symbolic rather than naturalistic, they apparently depict some Tree of Life, here given features of the vine but also - since its fruits are not grapes - perhapes pomegranates. Equally significant is the use of red ochre: out of all available pigments this red oxide of iron was chosen, clearly for its traditional and close resemblance to blood, which the ancient Maltese, like so many others, surely thought of as the life-force, and which in all probability they collected from the dying animal during sacrificial ritual and poured as a libation to the Earth. There is sufficient evidence that this rite was performed in the Hypogeum itself, as well as in the Maltese temples and over much of the ancient world. And this act of libation was no idle act, but one performed with the deliberate, pious and conscious intent of revitalising the Earth from which all life ultimately springs. At Hal Saflieni the blood-coloured ochre is painted directly onto the walls and ceilings of the Hypogeum, itself symbolically a womb. The symbolism could hardly be clearer, especially as the Trees of Life painted there bear fruits which are perhaps pomegranates, the fruit associated in the Persephone myth with death and the rebirth of life. The one intact burial was crouched in the foetal position, as if awaiting rebirth.

Here finally I have deliberately passed into the realm of philosophy. There is nothing impossible or improbable about a Maltese belief in reincarnation, which could come quite naturally to a people 'worshipping' a corn goddess associated with vegetative death and rebirth. Such ideas were indeed common in the ancient worid. Among the classical Greeks, two of the most brilliant minds, Plato and Pythagoras, deliberately used myths of reincarnation, and both were consciously archaising. India provides an example where this ancient 
belief, not destroyed by subsequent religious reforms, survives to the present day. Indeed, knowledge of an afterlife is not possible, though reflecting and imagining about it is part of the common human heritage. The neolithic Maltese were pre-literate, but in their temples and the Hypogeum they developed an art form that is symbolic. It is either anachronistic or simplistic to write off this sacred art as 'decorative': the spiral carvings at Tarxien and Ggantija could very well symbolically represent a belief in reincarnation, associated with a matrilinear genealogy. I have consciously wandered far from verifiable facts in order to derive the beliefs of the ancient Maltese from their material remains, so far as this is possible. Although my attempt is only a hypothesis, it has the virtue of being a reasonable explanation, of being self-consistent, and also of being consistent within the archaeological context left by the neolithic Maltese farming community. They would have been exceptional had they had no beliefs.

At last we are in a position to explain why certain of these farming women may have gone to the Hypogeum for 'incubatory dreams'. They went there, as they thought, to conceive, to become pregnant, or, more exactly, to improve their chances of doing so. Throughout the Early Neolithic period, like many, presumably most, very early societies, the ancient Maltese had neither worked out nor articulated the causal relationship between sexual intercourse and pregnancy. Instead we deduce that their ideas included some kind of reincarnation, that is, of pregnancy occuring due to a spirit-child choosing and entering a woman's womb and developing there. In Malta it seems that some of the women of the Tarxien clan or kinship group went to the Hypogeum, that sacred resting place of their ancestors, to have an 'incubatory dream' in one of the chambers there, in order to be chosen by a spirit-child and come out pregnant. This ritual act would in no way have interfered with their leading a normal and healthy sex life with their consorts! They simply did not connect the sexual act with pregnancy. And so perhaps the terracotta model of the Sleeping Lady was sculpted as a result of a pregnancy which coincided with an act of ritual incubation, and was in fact presented as a votive thank-offering to the ancestral cult site, the Hypogeum. 


\section{Summary}

As prehistory reaches further back into forgotten millennia, we run the risk of serious anachronisms. Different categories of material objects are unearthed, some quite enigmatic; study techniques should incorporate description, comparison, and reference to archaeological and social contexts. At Tarxien the 'Fat Lady' stands on a plinth sculpted with shapes best interpreted as querns and grains, pointing to a corn-goddess of the Demeter type. The Hypogeum's main function was burial, probably of a minority group and associated with reverence for ancestors. Evidently there was also a cult of incubation, classically associated with healing. Red ochre paintings in the Hypogeum show vines (Trees of Life) with perhaps pomegranates, associated with death and rebirth as in the cult of Persephone, who apparently had a temple in Malta. A general knowledge of the male role in procreation is unproved for the Early Neolithic. As the Hypogeum was the context for the cult, incubation there appears linked with death and rebirth, possibly some 'reincarnation'. The Sleeping Lady could be an ex-voto terracotta given for a pregnancy posterior to an act of incubation.

\section{Resumé}

Notre connaissance des millénnaires préhistoriques augmente toujours, mais porte le danger d'anachronismes sérieux. Certains objets trouvés restent énigmatiques: nous devons les étudier avec référence à leur contexte archéologique et sociologique. A Tarxien, la grande figure d'une déesse reste sur une plinthe gravée en images mieux interpretées comme meules et grains, indiquant une déesse des céréales du type de Déméter. La fonction principale de l'Hypogée serait la sépulture d'une minorité, lieu donc de révérence aux ancêtres, et aussi d'un probable culte d'incubation, associé par les Grecs avec la guérison. Dans cet Hypogée la pienture en ocre rouge démontre des vignes (Arbres de la Vie) et peut-être des grenades, associées avec la mort et la renaissance, surtout dans le culte de Persephone, qui apparemment avait un temple à l'île de Malte. Une connaissance générale du rôle masculin dans la procréation reste sans preuve pour le Néolithique inférieur. Comme l'Hypogée était le contexte pour le culte, l'incubation était évidemment liée à la mort et à la renaissance - ou une réincarnation. Peut-être la figurine The Sleeping Lady est un exvoto en terre-cuite presenté pour une grossesse postérieur à une acte d'incubation rituelle dans l'Hypogée. 
Bibliography

CHAMPION, GAMBLE, SHENNAN \& WHITTLE

1984 - Prehistoric Europe, London.

EVANS, J.D.

1971 - Prehistoric Antiquities of the Maltese Islands, London (Athlone Press).

RIDLEY, M.

1976 - The Megalithic Art of the Maltese Islands, Poole (Dolphin Press). TRUMP, D.H.

1980 - The Prehistory of the Mediterranean, London (Alien Lane).

HARRISON, J.E.

1980 - Prolegomena to the Study of Greek Religion, London (Merlin).

EVANS, J.D.

1979 - Blue Guide, Malta, London (Ernest Benn Ltd.).

GIMBUTAS, M.

1983 - The Goddesses and Gods of Old Europe,London (Thames \& Hudson). 